\title{
Some Specific Aspects And Forms Of Islamic Civil Law.
}

\section{RakhmanovAbdumukhtorRejjabbaevich}

Tashkent State University of law, Associate Professor of the Department of International Law and Human Rights, Doctor of Philosophy law.

\begin{abstract}
The article deals with the issues connected withthe oath,debtand guaranteein Islamic law. The oath can be admitted only by adult and sane person. The Islamic law rules on oaths, debts and suretyship are unique.It is forbidden to swear by anything other than the name of Allah. If he swears in the name of Allah, he should have to keep his oath. If he forswears, he atones for his sin - kaffarat. According to Islamic studies, no matter what hardships a person faces, Muslims should extend a helping hand to him. When a person is in a difficult financial situation, when he feels the need for money to meet his basic needs for food, shelter, treatment, etc., he should rush to help him with debt and help him as much as possible without usury, fraud and deception.
\end{abstract}

Keywords: oath, ghamus, cancellation, munaqid, sharia, falsehood, ayman, mahlufun-alayh, covenant, wajib, mustahab, debt, debtor, expiation, usury, haram, dirham, fard, mandub, mubah, halal, guarantee.

Article Received: 16th October, 2020; Article Revised: 30th December, 2020; Article Accepted: 08th January, 2021

Some specific aspects and forms of Islamic civil law.

Islamic law based on Islam is a mature phenomenon of medieval Eastern civilization. This legal system emerged within the framework of the Arab Caliphate and gradually gained international significance. The process of its development is closely connected with the process of the Arab statehood from a small religious community in the early VII century, ie in the time of Muhammad (pbuh) to one of the large empires in the VIII-X centuries during the Umayyads and Abbasids. Islamic scholars have developed legal doctrines and norms that have a legal nature while maintaining the basic rules of Sharia.

If we look at the history of Islam, Imam alBukhari, Burhaniddin Marginani, Bahauddin Naqshband, Imam at-Termizi, Khoja Bahauddin Naqshband, Khoja Ahmad Yassavi, al-Khwarizmi, Beruni, Ibn Sino, Amir Temur, Mirzo Ulugbek, Zahiriddin Babur and other great Movarounnahr The great contribution of muhaddithin and mujtahid scholars to the development of Islamic culture and law is recognized by the entire Islamic world.
The works of these great scholars have played an important role in strengthening the foundations of Islam and the development of Islamic thought for centuries. [1, P.148.]

The following words of the President of the Republic of Uzbekistan Sh. Mirziyoyev are noteworthy: "We are building an international research center named after Imam Bukhari in Samarkand, and a center of Islamic civilization in Tashkent. We are not doing these things to show off to anyone. Our goal is to inculcate in our children the true human nature of Islam, enlightened Islam. In this way, they will come to such places and gain the necessary knowledge and insights about what great deeds our great ancestors have accomplished. Most importantly, a sense of pride in our rich history and cultural heritage will grow in their hearts "'[2, P.25].

Great work is being done in the Republic of Uzbekistan to ensure religious tolerance, preserve and promote enlightened Islamic values. The Center for Islamic Civilization in Uzbekistan, Imam Bukhari, Abu Isa Muhammad Termizi, international research centers named after 
our great scholars have been established, opportunities for religious education are expanding, the rights of believers are protected and conditions are created for them.

The adoption of a special resolution on "Enlightenment and Religious Tolerance" at the plenary session of the UN General Assembly was a bright manifestation of the initiative of Uzbekistan on religious tolerance. Adopted on the initiative of President Shavkat Mirziyoyev at the 72nd session of the UN General Assembly in 2017, this document serves to strengthen the existing culture of religious enlightenment tolerance among the peoples of the world. [3, http: //uza.uz/posts/58007]

These historical events testify to the fact that the reforms being carried out in Uzbekistan in the field of Islam are recognized in the world, and our country has a rich history and experience in these areas.

Various studies on Islamic law are being conducted in Uzbekistan. Of these, we would like to focus on the issues of oath and debt in Islam.

There is an oath in Islamic law, but an oath is taken only in the name of Allah. An oath taken by mentioning the names of Allah, for example: vallahi, billahi, is considered to have legal force in the Shari'ah. Today, swearing by the Qur'an has become a tradition. But in Islam it commands not to swear as much as possible. "Do not oppose Allah (swt) for your oaths of good deeds, piety, and reform among the people. Allah is AllHearing, All-Knowing "(Surat al-Baqara, 224) [4, P.21]. If there is a need to swear, only in the name of Allah. Muhammad (pbuh): "Whoever swears, let him drink in the name of Allah, or be silent (ie, let him not swear)" (Narrated by Muslim). There are three types of oaths under Islamic law: ghumus (false), lagw (vain) and munaqid (bound). Swearing falsely for what has happened is called Ghumus. For example, it is an oath to say, "By God, I did not do it," after doing something. The oath of allegiance is a great sin in Islamic law.

An annulment is an oath taken on suspicion that something has happened. For example, a man may say to a friend, "By God, I saw you in the market yesterday," when in fact he is misleading his friend with another.

Munaqid is an oath to do or not to do something in the future. If such an oath is broken, that is, if it is not fulfilled, atonement becomes obligatory. Atonement is obligatory if the munaqid oath is forgotten, misguided, compelled or intentionally violated. Even if a person takes such an oath not voluntarily, but under duress - it takes effect. Our Prophet Muhammad (pbuh) said: "Three things are serious and both jokes are serious: marriage, divorce, oath [5, p.4]." Words such as "Let the Qur'an strike" are not considered oaths. But if he says, "I swear by the Qur'an," the oath is taken into account. The common saying, "God forbid," is also considered by some scholars to be an oath. He also swears by those who say, "I swear," "I swear," "I testify." It is also an oath to defile what is honest. For example, if he says, "I have defiled myself with honey," he must keep his oath, and if he breaks it, he will pay atonement.

In Islamic law, it is wrong to swear an oath for a sinful act. For example, "By God, I will not talk to my father or hit someone." But he keeps swearing to her. Islam violates such an oath and commands atonement [6, p.18-20].

"Allah will not hold you accountable for your oaths in vain. But it holds for your oaths that you have deliberately shed. So his expiation is to give food or clothing to ten poor people in the amount of the average food of his people, or to free a slave. And whoever does not find, then let him fast for three days. That, if you swear, is the expiation of your oath. Keep your oaths. God thus explains His revelations to you. Perhaps you will be grateful. (Qur'an, Surat al-Ma'ida, 89) [5, p.42]. 
When swearing in places permitted by the Shari'ah, it is drunk only in the name of Allah. It is wrong to swear in the name of Allah. Swearing, swearing, taking an oath has legal significance in the first place. Islamic law requires a person to take an oath voluntarily, not under duress. It is not good to swear in a hasty manner without thinking of the consequences. If a person swears to give his wealth to the poor and he himself goes bankrupt as a result, such an oath is considered invalid.

"Ayman" means "oath". In Arabic, "ayman" is the plural form of the word "yamin". The original meaning of the word 'Yamin' is 'power' or 'authority' as well as 'right hand'. The obligation of a person who has taken an oath to perform a certain act or to refrain from doing so is expressed in the language of the law by the term "yamin". A person who takes an oath or takes an oath is called a caliph, and the object of the oath is called a mahlufun alayh. [6, P.64].

One of the leading scholars of the Islamic world, Burhaniddin Marginoni's Hidoya, Chapter IX, is entitled "On Covenants in Trade, Marriage and Other Fields" [7, P.353]. In this case, the oath of non-performance of certain works shall not be considered invalid if they were performed by a third party. For example, if a person swears not to engage in trade, not to rent or lease real property, and then appoints his representative to carry out sales and other similar transactions, he will not break his oath. In this case, he is not directly involved in the transaction, as long as he is an interested party. For him, the outcome of the deal is more important than the deal. Except in cases when the person who swears not to enter into a contract wants to enter into a contract or is not accustomed to concluding a contract himself due to the fact that he holds a position. If a person who has taken an oath seems to be ordering another person to take action in his place, it is a breach of oath. This is because it is inherent in a person holding a position to enter into sales and other similar transactions through others. He therefore ordered others to enter into a sale and purchase agreement, and if that order was complied with, he would have broken the oath.

Chapter XIII of Hidoya deals with money, lending and debt repayment. Here it is necessary to determine the difference between the time of swearing and the word 'fast'. If a person swears, "I will pay my debt to So-and-so quickly," it is up to a month, and if he says, "I will pay my debt to So-and-so on time," it is more than a month. Because the time interval of up to a month is a short period, and the interval of more than a month - a long period. Therefore, when people who have not seen each other for a long time meet, one usually tells the other, "We have not seen each other for a month" [8, p.464]. In this case, it is important not only to pay the debt, but also to pay it on time. Debt cannot be repaid with money taken from someone.

A person who swears to pay a debt can do so by paying off the debt. If the person who took the oath sells his slave to the lender in exchange for the debt he owes, and the lender agrees to it, then he has fulfilled his oath, because the termination of the debt, i.e. one of the parties fulfilling the debt obligation of the other party, is one way

B. In Marginoni's Hidoya, the oath to pay the debt is not fulfilled when the lender waives the debt. For example, if the lender waives the debt on the day of the oath, it will not cause the oath to be fulfilled, because in that case the debt will not be repaid in practice. However, even if the oath-taking promise is not fulfilled, in this case the oath will not exist, but the oath taken will lose its force. This is because the oath taken is limited to the day on which it is mentioned. As long as the lender waives the debt during that day, the person who took the oath will be deprived of the opportunity to fulfill his oath before the expiration of this period. As a result, the oath loses its legal force. 
It should also be noted at this point that an oath taken to pay a debt in installments is not considered to have been broken unless the entire debt is paid in full in this way.

Burhaniddin Marghinoni explains the situation as follows: If the borrower swears to pay his debt to the lender in installments, the lender will say to him, "I will receive the loan in full, not in installments," and then in installments. unless the whole debt is repaid in this way, the oath shall not be deemed to have been broken, because in this case the oath shall be broken until the debt is paid in full, but in installments.

If the lender asks the debtor to pay a portion of the debt, for example, two hundred dirhams, the debtor replies, "If I have more than a hundred dirhams, let my wife be divorced," and if he has fifty dirhams in cash at that time, the oath is not broken. . In fact, at the same time, the debtor wanted to express that he did not have more than a hundred dirhams with the above-mentioned words. One hundred dirhams can cover any part of the face. Since fifty is one of these parts, the oath is not considered broken either. The above rule also applies when the debtor says "I have more money than a hundred dirhams" or "more than a hundred dirhams" instead of "more than a hundred dirhams" [9, B. 482].

As far as family members are concerned, not everyone has the right to take an oath in the family under Islamic law. Wives and children are not entitled to swear without the consent of their husbands and fathers. If they took an oath without the permission of their husband and father, such an oath is not considered valid. A son who assumes his father's oath without the consent of his father must fulfill this oath, unless the father objects.

It is obligatory to swear only in places specified in the Shari'ah. For example, in the presence of a judge. At other times it is not permissible to take oaths in vain.
According to Islamic law, only an adult and a sane person can take an oath. Oaths taken by children, mentally retarded people, as well as oaths taken while intoxicated and under pressure, will not be valid. It is forbidden to swear under strong excitement. Oaths related to doing things that are forbidden or forbidden in Islam are also not considered valid. From the Islamic point of view, it is forbidden to take an oath that is obligatory and mustahab, that is, an obligation that is obligatory (for example, it is not permissible to swear to perform the five obligatory prayers that are obligatory for every Muslim).

Since the name of Allah must be mentioned in the oath, it is forbidden to swear orally or to write the oath on paper. Dumb people are more than that, they can swear by gestures. [10, B.102]

In Arabic, the word 'kaffarah' means to cover something up nicely and invisibly. In the Shari'ah, however, the financial or physical prayer performed to atone for a sin committed is called atonement. The atonement to be paid by a person who swears and fails to do so is, first of all, to feed the stomachs of the ten poor. If he does not want to give food, he will give ten poor people a headdress. If a person who violates the oath does not have the financial means to fulfill these conditions, he must fast for at least three days [11, p.86].

Islam strictly regulates trade and economic relations and debt obligations between Muslims. Lending is considered a good deed in Islamic teaching. It is obligatory for every Muslim to provide material support to the poor, orphans and widows, to help them live a decent life.

This is mentioned a lot in the Qur'an and the hadiths. Muhammad (pbuh) said: "Whoever relieves a Muslim of one of the sorrows of this world, Allah will alleviate one of his sorrows on the Day of Resurrection. Whoever relieves the burden of a tormented Muslim in this world, Allah will lighten his burden on the Day of Resurrection. Whoever conceals the guilt 
of a Muslim in this world, Allah will conceal his guilt in this world and in the Hereafter. As long as one slave helps another slave, Allah will help him as well "'[12, P.254].

One of the important duties in Islam is to alleviate the burden of one's Muslim brother, to lend him a helping hand in difficult times, to sympathize with his grief, and to lend to him when necessary.

Imam al-Bukhari and Imam Muslim quoted the Prophet (peace and blessings of Allaah be upon him) as saying: "Muslims should admonish one another and be compassionate to one another. For example, if one of the limbs in the body is in pain, the other limbs will be sympathetically awake until the pain goes away.

According to Islamic teachings, there are difficulties in life. Consequently, there will also be difficulties and worries in the life of a Muslim, such as financial hardship. In such cases, he will have to ask someone for a loan. "Whoever lends to Allah a good (good) loan, He will repay it to him several times" (Qur'an, 2: 245).

Muhammad (pbuh) said: "A Muslim is the brother of a Muslim, he does not betray him, he does not lie, he does not deceive" (Imam al-Bukhari, Imam Muslim). "Whoever lends a dirham to a believer twice, one of them will be spent on charity" (Imam al-Bukhari) [13, p.326].

In Islam, the reward of lending may be superior to the reward of charity. It depends on who, to what person, the charity is given and the condition of the person who is lent. At the same time, it should be noted that if a debt repayment period is set, the debtor must repay it on time, and the lender must not claim the debt before that date. Delaying the repayment of a debt without a reason is a sin in Islam. However, if the debtor has nothing but the house in which he lives and the necessary household items, the lender should not demand repayment of the debt and wait for its return. If a debtor who is unable to repay his debt is able to work, he must repay the debt with his own labor [14, P.126].

Islamic law does not allow a debtor to take over a debt, and if he cannot find a lender to repay it, he orders it to be given to the poor. If the debtor has received a certain amount of money in gold or silver, and then the price has risen or fallen, the amount to be returned is agreed between the debtor and the lender.

According to Islamic teachings, doing things in a hurry, patiently, or speaking in a hurry without thinking can lead to bad consequences. There are only three things that should be done in a hurry:

Islamic law prohibits interest on loans. If the lender stipulates repayment with interest at the time of the loan, it is usury, that is, usury, and it is haram. Usury (interest) on money usury is one of the major sins in Islam. It is strictly forbidden in the verses of the Qur'an. Profiting from money further increases the wealth of the rich, leaving the poor more vulnerable and subjecting them to debt obligations.

"Those who devour usury will not be able to defeat the devil but will be like a madman. This is because they say that trade is like usury. And Allah has made trade lawful and usury unlawful. Whoever stops when a sermon comes from his Lord, the past is for himself, and his affair is for Allah. Whoever returns to usury is the owner of Hell. They will abide therein forever. (Qur'an, Surat al-Baqara, 275)

"Allah always reduces usury and increases charity. And Allah does not like every disbeliever and sinner. (Surat alBaqara, 276)

"O you who believe, fear Allah, and give up usury, if you are true believers." (Qur'an, Surat al-Baqara, 278) [15, p.61].

Usury is also condemned in the hadiths. The Prophet (peace and blessings of Allaah be upon him) said: "Allaah curses the usurer, the usurer, the witnesses and the scribes." (Imam al-Bukhari) [16, p.253].

Riba (Arabic usury) means to make money. Before Islam, usury was common 
among the Arabs. While trade and profitmaking were widely encouraged in early Islam, it was strictly forbidden to profit from money, and this prohibition was also reflected in the Qur'an. The surahs and verses mentioned above are examples of this. This prohibition still applies to banking and finance in Muslim countries.

So, making money is strictly forbidden in Islam. But the borrower can satisfy the lender in a certain way. For example, without using the word 'usury', it is permissible to invite a lender as a guest, to give him a gift, to thank him with kind words, and so on. Islam approves of such behavior.

Halal (Arabic free, unbound) - to allow; permissible behaviors that fall within the concepts of fard, mandub, and mubah; is the opposite of forbidden behavior (haram). Issues about halal are studied by the ruling section of fiqh.

Haram (Arabic forbidden, forbidden) - consists of things that are clearly forbidden in the Shari'ah, no doubt. According to Islamic teachings, it is haram for a parent to be white, fornication, usury, theft, robbery, bribery, espionage, slander, lying, murder, unjust bloodshed, betrayal, trade fraud, gossip, and slander. These actions are prohibited by Islamic sources and are punishable.

In any case, if the lender uses the surcharge for the loan for his own needs, including even for religious purposes, it is considered an interest rate and is prohibited. For example, Islamic law prohibits the purchase of clothing and prayers for borrowed money. The lender may instruct its representative to collect the loan amount from the debtor. When a representative receives a loan from a debtor, he becomes a debtor before that lender, and the lender loses the right to demand a loan from the first borrower. If the debtor has pledged part of his property to the creditor, in the event of nonrepayment of the loan, the lender has the right under Islamic law to use the collateral on the loan account or deduct the amount of the loan from it.

From the point of view of Islamic law, items or property that can be sold, bought and used can be pledged. The debtor is obliged to pledge a part of his property or a part of the property belonging to another person to the lender with the consent of the owner. The lender and the debtor have no right to sell or gift the pledged property without the consent of the owner. If the lender sells the mortgaged property with the consent of the debtor, the proceeds are also considered collateral. If the borrower does not repay the loan after the deadline, the lender can use the collateral left with him. But Islamic law advises resolving this issue only in court so that there is no dispute between the lender and the debtor.

A guarantee - (Arabic guarantee) - is a type of contract under which the guarantor undertakes to be liable to the lender for the full or partial performance of its obligations by the debtor [17, p.62].

A guarantee is one of the ways to ensure the fulfillment of obligations. A guarantee agreement may also be entered into to secure a future obligation.

If someone wants to be a guarantor and tells the lender that he is willing to take on the obligation to repay the debt in lieu of the debtor, the consent of the debtor is not required if the lender agrees.

The similarity of this phenomenon in Islamic jurisprudence does not exist in the system of western jurisprudence. It is noteworthy that a person who wants to provide a guarantee and recover a debt from a debtor may or may not inform the debtor about it, depending on the situation. The debtor, as a rule, may guess who saved himself from the debt or may not know it until the end of his life. In practice, this is done as follows: any selfsatisfied person finds out that one of his acquaintances is unable to repay the debt. In order not to embarrass the debtor, this man secretly comes to the lender from him 
and extends his debt. This is one of the forms of charitable activity.

The guarantor is considered invalid (void) if the guarantor informs the lender that he will pay the debt instead if the debtor does not repay the debt.

A person can assume a guarantee only if the lender is the debtor, the type and amount of the loan is clear. If the lender has gifted the debt to the guarantor, he is not entitled to claim the debt from the debtor.

If a certain person has guaranteed the repayment of a particular debtor's debt, he should not waive his guarantee.

If a person defaults on his debt without the debtor's permission, he has no right to demand anything from the debtor.

If a person decides to pay off his debt with the consent of the debtor, he can assume part of that debt. However, if the guarantor has agreed with the lender to repay the debtor's debt with other goods or items, he has no right to demand the same goods or items from the debtor. For example, if the debtor has borrowed flour and the guarantor has repaid the debt with rice, the guarantor has no right to demand rice from the debtor, except in cases where the debtor himself has decided to give him rice.

Giving a guarantee to a lender to repay a debt at any time at his request is called a "guarantee" in Islamic law. A person who assumes the obligation under a guarantee is called a "guarantor".

The warranty is void in the following five cases:

- when the guarantor returns the guarantee on demand;

- Lender - when the loan is repaid to the claimant;

claim;

- when the claimant waives his

- in case of death of the debtor;

- when the claimant voluntarily released the guarantor from the guarantor [18, p.251].

Islamic law prohibits hiding a debtor from a lender. The person who commits such a case must hand over the debtor to the lender.

In conclusion, the system of rules of Islamic law on oaths, debts and sureties is characterized by the complexity of economic relations. It is forbidden to swear by anything other than the name of Allah. If he swears in the name of Allah, he will have to do it. If Moboda fails to fulfill this oath, he will atone. Islam forbids swearing. As long as a Muslim feels that he will answer every word that comes out of his mouth on the Day of Judgment, he will not lie and will not need to swear. If there is a need to swear, the oath should be taken only in the name of Allah and it should be fulfilled. According to Islamic teachings, when a person is in a difficult financial situation and feels the need for money to meet his basic needs, Muslims should rush to his aid and help him as much as possible without usury, fraud and deception. We believe that it is important to study the Islamic norms that are preserved in our country today as a norm, and to convey to our people the true state.

\section{REFERENCES:}

1. Raxmanov A. Raxmanov A. Islamic law. - T. "New Age Generation", 2003. B. 348-350.

2. Sh. Mirziyoev. The consent of our people is the highest value given to our activities. T. Uzbekistan. 2018. -B. 25.

3.https: //uza.uz/uz/posts/president-islamcivilizasiya-markaziga-tashrif-buyur-2112-2018

4. The Holy Quran. Translation by Sheikh Muhammad Sadiq Muhammad Yusuf. -T. Crescent edition. 2017.

5. Imam al-Bukhari's work "Al-Jami 'assahih" Hilal-edition. 2019.

6. S.Iskhakov. Fundamentals of Islamic Civil Law MIA Academy. 2005. - Б. 64

7. B. Marginoni Hidoya, part 4, manuscript form. Page 353.

8. B. Marginoni Hidoya, part 4, manuscript form.464 p. 
9. B. Marginoni Hidoya, part 4, manuscript form.

10.Raxmanov A. Sushchnost dogovorov in Islamic law and national legislation of the Republic of Uzbekistan. Monograph. -T. MIA Academy 2005. -S. 350.

11.S.Iskhakov Fundamentals of Islamic Civil Law T. MIA Academy. 2005. - Б. 102.

12. Abu Musa Termezi. "Sahihi Termizi". G'. Literature and art named after Ghulam. -T. 1993.-B. 254.

13. Al-Jami 'as-Sahih by Imam al-Bukhari, Hilal-Nashr. 2019.

14.S.Iskhakov Fundamentals of Islamic Civil Law T. MIA Academy. 2005. - B 126.

15. The Holy Quran. Translation by Sheikh Muhammad Sadiq Muhammad Yusuf. -T. Crescent edition. 2017.

16. Imam al-Bukhari's work "Al-Jami 'assahih" Hilal-edition.2019. B.253.

17. Raxmanov A. Sushchnost dogovorov in Islamic law and national legislation of the Republic of Uzbekistan. Monograph. -T. MIA Academy 2005. -S. 350.

18. Raxmanov A. Raxmanov A. Islamic law. A new generation. -T. 2003. -S. 380. 